\title{
Expression of Id2 in the developing limb is associated with zones of active BMP signaling and marks the regions of growth and differentiation of the developing digits
}

\author{
CARLOS I. LORDA-DIEZ, NURIA TORRE-PÉREZ, JUAN A. GARCÍA-PORRERO, JUAN M. HURLE* \\ and JUAN A. MONTERO \\ Departamento de Anatomía y Biología Celular, Universidad de Cantabria, Santander 39011, Spain
}

\begin{abstract}
Here we report the pattern of expression of inhibitor of DNA binding/differentiation factor 2 (Id2) in the developing chicken limb. We show that prior to stage 25, Id2 is expressed in the anterior and posterior mesoderm, the AER, and in the early skeletal chondrogenic aggregates. At more advanced stages of limb development $I d 2$ is expressed in the undifferentiated subectodermal and interdigital mesenchyme and exhibits specific domains of expression in the growing digits. These expression domains were closely coincident with zones of activation of BMP-signaling as deduced from the distribution of phosphorylated SMADs 1/5/8. In micromass cultures transcripts of $I d 2$ are associated with the nodules of chondrogenic differentiation. Expression of $I d 2$ both in vivo and in vitro was up-regulated in experiments of BMP-gain-offunction and down-regulated after treatments with BMP-antagonists. Interestingly, interdigital application of TGF 32 transiently upregulates $I d 2$ in coincidence with the inhibition of interdigital cell death and the commitment of the interdigital mesenchyme to form an ectopic digit. These data suggest that Id2 is a molecular mediator of BMP signaling acting in concert with the TGF $\beta$ pathway during the formation of the digits.
\end{abstract}

KEY WORDS: chondrogenesis, interdigital cell death, cell proliferation, p-Smad, tendon differentiation

\section{Introduction}

The primordia of the vertebrate limbs develop in the lateral surface of the embryonic body by proliferation of the lateral plate mesoderm. These early growing buds are simple structures consisting of a core of mesodermal cells covered by an ectodermal jacket. In the course of development the bud undergoes intense outgrowth and the cartilaginous primordium of the skeletal components differentiates in the central region of the mesodermal core. At difference of these central cells destined to form cartilage, cells surrounding the chondrogenic aggregates are largely eliminated by apoptosis sculpturing the shape of the definitive limb. The opposite chondrogenic and apoptotic fates of the mesodermal cells are particularly relevant during the formation of the digits in the autopodial segment of the limb. In this region digits develop as diverging chondrogenic rays joined by intervening interdigital tissue, which will later be removed by massive apoptotic cell death in species with free digits (ZuzarteLuis and Hurle, 2002).
Bone morphogenetic proteins (BMPs), Activins and transforming growth factor $\beta 2$ (TGF $\beta 2$ ) are the main signaling molecules modulating digit morphogenesis. TGF $\beta 2$ and activins are expressed incipiently in the mesenchyme that will generate a digit in the developing autopod. Additionally, ectopic overexpression of any of them in the interdigital tissue inhibits its apoptotic fate and induces the formation of an additional extra-digit (Ganan et al., 1996, Merino et al., 1999a, Montero and Hurle, 2007). Bone morphogenetic proteins (BMP2, BMP4, BMP7 and BMP5) are expressed in the interdigital and peridigital tissue, rather than in the digit aggregates, but they are responsible for the outgrowth of the digit cartilages (Montero and Hurle, 2007). Accordingly, overexpression of BMPs in the digit mesenchyme generates a dramatic overgrowth of the digits while overexpression of BMP

\footnotetext{
Abbreviations used in this paper: AER, apical ectodermal ridge; BMP, bone morphogenetic protein; Id2, inhibitor of DNA binding/differentiation factor2; TGF, transforming growth factor.
}

\footnotetext{
*Address correspondence to: Dr. Juan M Hurlé. Departamento de Anatomía y Biología Celular. Facultad de Medicina. C/ Cardenal Herrera Oria s/n. Santander. 39011. Spain. Fax: +34-942-201-903. e-mail: hurlej@unican.es http://grupos.unican.es/apoptosis
} 
antagonists (i.e. noggin or gremlin) results in digit truncation (Merino et al., 1998, Merino et al., 1999b) A remarkable aspect of BMP signaling during limb development is that in addition to promotion of the growth of skeletal cartilages, they are also the triggering signals of programmed cell death in the undifferentiated mesoderm, including the interdigital mesenchyme (Ganan et al., 1996, Macias et al., 1997). Therefore unraveling the functional coordination between TGF $\beta$ /activin and BMPs in regulating growth and differentiation of the cartilaginous skeletal primordia and programmed cell death is a major question to understand digit morphogenesis. Hence, the identification of intermediate players of both signaling pathways can be particularly helpful for this purpose.

The Id (inhibitor of DNA binding/differentiation) proteins are a subfamily of the helix-loop-helix factors that contain an HLH dimerization motif but lack a basic DNA binding domain. The Id family contains four members (Id1, Id2, Id3 and Id4) and was initially discovered as inhibitors of cell differentiation functioning as antagonists of basic helix loop helix (bHLH) transcription factors (also called E-proteins). Thus, after heterodimerization with these type of transcription factors they impair its binding to the specific E-Box domains of the DNA due to the lack of DNA binding regions (Benezra etal., 1990). It is now known that they can also inhibit the action of other transcription factors as Pax or Ets (Roberts et al., 2001, Yates et al., 1999). During development Id1, Id2 and Id3 possess overlapping patterns of ex- pression showing only slight differences while $/ d 4$ differs from the rest of the family members (Jen et al., 1996).

The double knock out mice for Id1 and Id3 (but not the single ones) display dramatic inhibition in neurogenesis and brain associated angiogenesis, and seem to be factors capable to modulate vascularization of tumors (Lyden et al., 1999). In these mutants neuroblast precociously abandon cell cycle, and show stronger and extended expression of determination and differentiation neurogenic bHLH factors correlating with premature terminal differentiation (Lyden et al., 1999). Additionally, Id1 and Id3 are expressed in the blood vessels of the central nervous system and the mutant forms aberrant endothelial cells with absence of branching and sprouting of the capillaries of the neuroectoderm displaying haemorrhages in the ventricular system. Interestingly mice defective in these factors are much less permissive to tumor growth due to defective angiogenesis within the invasive tissue (Lyden et al., 1999).

Several defects are also associated to the lack of /d2in mice. $I d 2$ is expressed in the dendritic cells (DC), which are potent antigen-presenting cells with a pivotal role in antigen-specific immune responses. Id2-/- mice lack Langerhans cells (LCs) (the cutaneous contingent of DCs) and the splenic number of DC is severely reduced. During hematopoietic development expression of /d2 is under the influence of TGF $\beta$ signalling and modulates the differentiation toward the DC lineage, repressing the B-cell fate (Hacker et al., 2003). Similarly it has been

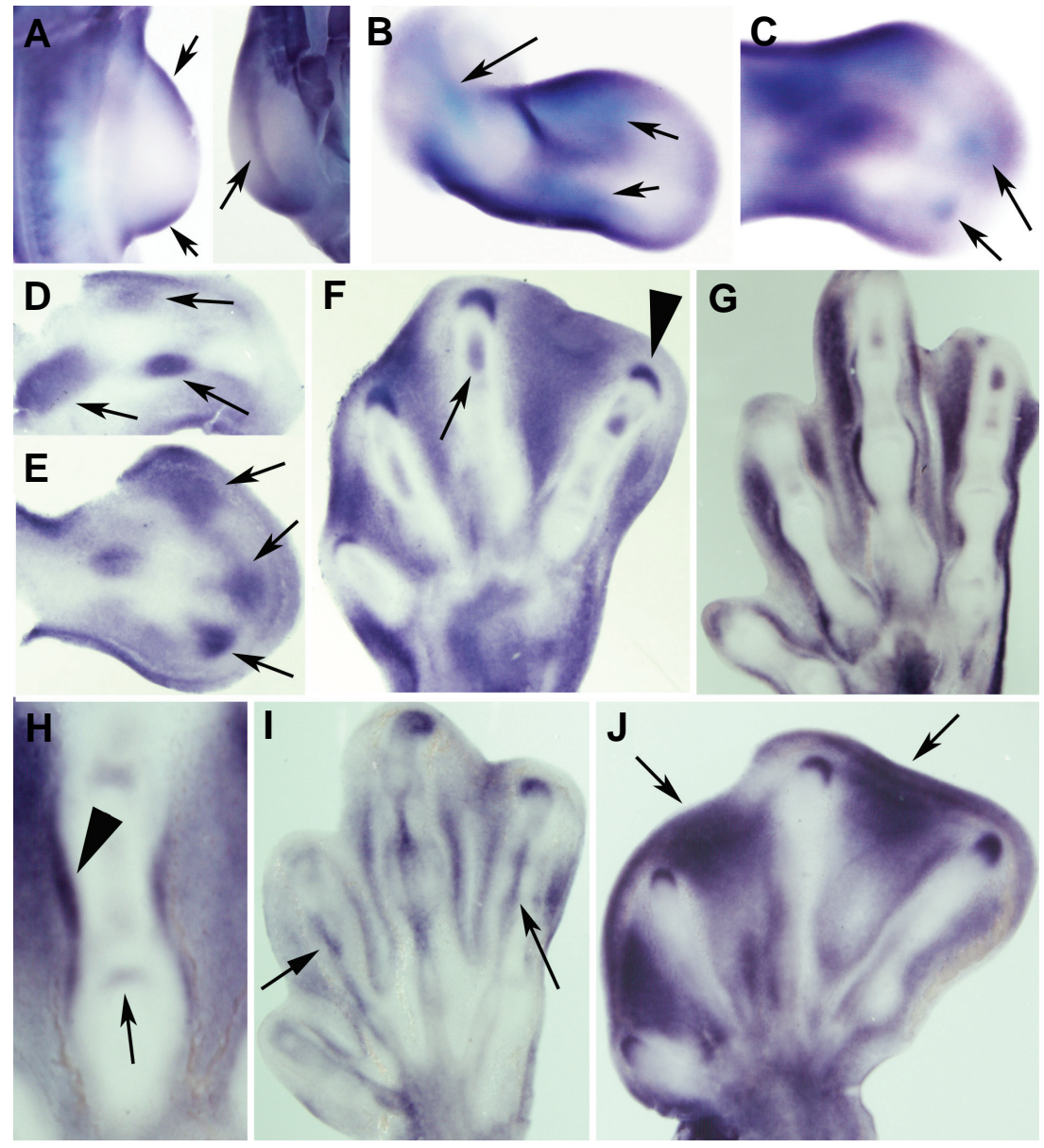

Fig. 1. Id2 expression in the developing limb of chicken and duck embryos. (A-J) In situ hybridization of chicken $(A-I)$ and Duck (J) embryos in whole mount $(A-C)$ and vibratome sections (D-J) specimens, showing the pattern of expression of Id2. (A) Image on the left of panel $A$ is a lateral view of the limb bud at stage HH21 showing domains of $\mathrm{Id} 2$ in the anterior and posterior mesenchyme (arrows). Image on the right of panel A illustrates a frontal view showing a moderate labeling (arrow) of the apical ectodermal ridge (AER). (B) Wing bud of stage HH24 showing Id2 expression in the anterior and posterior mesenchyme with additional domains in the forming skeletal elements of the stylopod and zeugopod (arrows). (C) Expression of Id2 is recognizable at the level of the forming digits at stage HH25 (arrows). (D) Vibratome section of a HH24 limb where domains at the level of the skeletal elements are more easily recognizable (arrows). (E) Vibratome section of stage 26 limb showing the expression of Id2 in the prospective digit mesenchyme (arrows). (F) Id2 is expressed in the interdigital mesenchyme, the digit tip (arrowhead) and the developing cartilage of the distal phalanxes (arrow) at stage HH 30. (G-H) Image in (G) shows appearance of transcripts at the level of the developing perichondrium of the digits and the articular cartilage of HH 34 autopod. These domains are more easily recognizable in a detailed view of a digit in (H) (arrow and arrowhead). (I) This panel shows a superficial section of the HH34 autopod of the chicken embryo showing further domains of expression at the level of the developing tendons (arrows). (J) Id2 is preferentially expressed in the distal mesenchyme of the interdigits 2 and 3 (arrows) of the developing duck autopod at 9 days of incubation (equivalent to chicken stage HH31) in contrast to the widespread interdigital distribution in first interdigit and in the chick autopod (F). 
propose that Id2 favors natural killer (NK) differentiation versus T cell linage from a common NK/T progenitor, thus Id2 null mice present a reduction of almost $90 \%$ of NK cells respect to wild type. Interestingly the number of precursors seems to be similar to wild type situation what indicates a clear constrain in cell fate decisions for these mice (Ikawa et al., 2001). In sum, Id2 nul/mice have severe reduction of natural killer cells and lack several subclasses of dendritic cells.

Additionally, Id2-nul/mice show alterations in the reproductive system. Thus, female null mice show lactation defects associated with defective cell cycle progression and drastic reduced proliferation of the mammary epithelial cells, which is required during early pregnancy (Mori etal., 2000). Male null mice present significantly reduced spermatogenesis with abnormal seminiferous tubules and dramatic reduction of sertoli cells consistent with the expression of /d2 in these cells (Sablitzky et al., 1998). It has been also shown that loss of $/ d 2$ in the intestinal epithelium prevents exit from cell cycle and differentiation of enterocyte precursor cells during embryogenesis. The maintenance of this situation in the adult life causes neoplastic transformation in adults (Russell et al., 2004). However, /d2 has an important oncogenic potential since is a direct target of the Myc family of transciption factors and is overexpressed in tumors carriying mutations in its members (Lasorella et al., 2002; Fernandez et al., 2003). Furthermore, it has been shown that only Id2, and not the other members of the family, Id1 and Id3, is able to abrogate the antiproliferative effects of tumor suppressor proteins of the retinoblastoma family allowing cell-cycle progression by physically interactions with them, (Lasorella et al., 2000).

Finally it is known that $/ d 4$ has an essential role in the maturation of oligodendrocytes during development, thus progenitors lacking Id4 precociously maturate (Marin-Husstege et al., 2006). In summary Id factors can work as important regulators of different biological processes and they are commonly associated to maintenance of undifferentiated state and the mitotic activity of cells, being often downregulated when cells differentiate (Lyden et al., 1999, Shimizu-Nishikawa et al., 1999; Ruzinova and Benezra, 2003, Sikder etal., 2003; Iavarone and Lasorella, 2006).

SMAD-binding elements has been reported in the promoter of Id proteins (Hollnagel et al., 1999). It has been also demonstrated that Id proteins contribute to coordinate proliferation and differentiation in cells subjected to BMP or TGF $\beta$ stimulation (Kowanetz et al., 2004). In addition it is known that /d2 is expressed in the early limb bud (Krishan etal., 2005). Therefore we have decided to explore the expression and regulation of this transcription factor during limb skeletal morphogenesis.

\section{Results}

\section{Id2 marks the limb regions regulated by BMP signalling}

We have examined the expression of $/ d 2$ in the limb bud by in situ hybridization using whole mount specimens and vibratome sections. At stages 21-22 transcripts are observed in the anterior and posterior mesenchyme and in the AER (Fig. 1A). By stage 2324 the anterior and posterior domains of expression increase in size and labeling intensity while transcripts are no longer observed in the AER. In addition, new domains of expression appear associated with the chondrogenic condensations of the stylopod and zeugopod (Fig. 1B and D). By stages 25, /d2 become expressed in the mesenchymal condensations of digits (Fig. 1C and E). From stage 27 the undifferentiated subectodermal mesenchyme including the interdigital mesoderm show considerable levels of gene expression and the initial digit domains appear now divided into different regions, rather than maintaining an uniform labeling (Fig. 1F and Fig. 3D-F). As shown in Fig. 1F and $1 \mathrm{I}$ a crescent domain of expression is associated with the tip of all the growing digits until the stage in which the last phalanx is formed. A zone lacking expression distally surrounds this domain. More proximally in the digit ray, the peripheral perichondrial region is negative for this gene while intense labeling is found at the central region of the future diaphysis of the developing phalanxes (Fig. $1 \mathrm{~F})$. A more tenuous labeling is also observed in the developing 

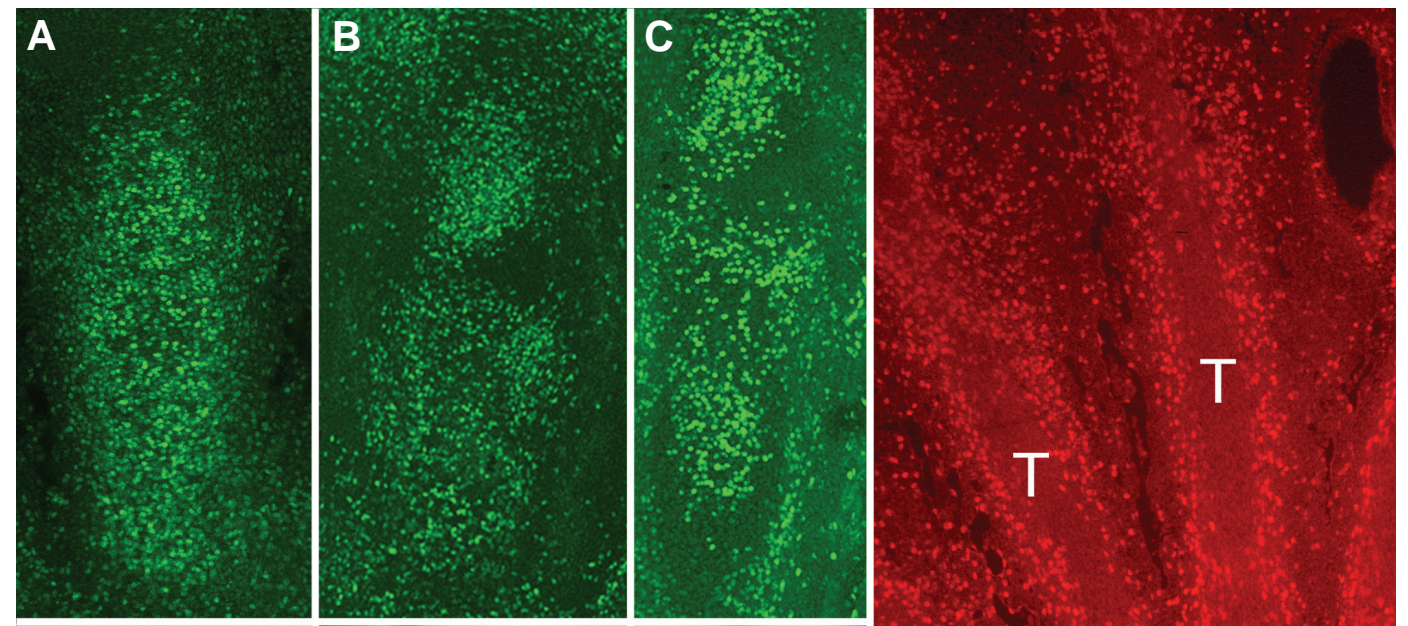

surfaces of the digits and the developing joints are initially negative for /d2in spite of the expression of BMP2, BMP7 and GDF5 in the perichondrium and developing joints. Furthermore previous reports have shown that the tip of the developing digits lack transcripts of BMP genes (see Montero and Hurle, 2007). In addition, it must be taken into account that domains of BMP expression are not necessarily associated with BMP signaling since they are secreted cytokines and several BMP antagonists, including Gremlin, Noggin, Ventroptin and Bambi are expressed in the developing autopod and may inhibit BMP signaling (ChimalMonroy et al., 2003, Grotewold et al., 2001, Merino et al., 1998, Merino etal. 1999b). Hence to clarify whether /d2 expression correlates with regions of active BMP signaling we examined by double in situhybridization the possible coexpression with Smad8, a BMP intracellular mediator, of which expression resembles that of $/ d 2$ (see Zuzarte et al., 2004). Indeed we found that both genes

epiphyses. In the neighboring regions of the developing joints, cartilage labeling is very tenuous although it can be recognized at the boundaries of the articular surfaces (Fig. 1H). From HH34 the expression in the differentiating cartilages becomes reduced, maintaining recognizable domains in the prospective articular cartilage of the developing joints. In addition at these stages tendinous and perichondrial domains are visible (Fig. $1 \mathrm{G}-\mathrm{H})$.

To check whether the interdigital domains of /d2 save correlation with apoptotic cell death we have studied its expression in the developing autopod of the duck embryo, where apoptotic domains are restricted to the distal-most mesenchyme of the webbed interdigits (Zuzarte-Luis and Hurle, 2002). As shown in Figure $1 \mathrm{~J} / d 2$ expression in duck is highly similar to that of the chick with the exception of the interdigital domains 2 and 3 , where transcripts are considerably more abundant at the level of the distal tissue.

\section{Id2 is a BMP response gene during digit development}

With some exceptions in the growing digits, most domains of expression of $/ d 2$ (see Fig. 1) correspond with regions in which members of the BMP family are expressed, suggesting that /d2 might be a BMP-response gene. However the perichondrial were coexpressed in all domains of expression, including the digital domains as shown in Fig. 2A. Furthermore, by immunohistochemistry we analyzed the distribution of phosphorylated SMADs $1 / 5 / 8$, transcription factors activated in regions of BMP activity (Massague et al., 2005), and we found that /d2 expression finely reproduced the pattern of distribution of $p$-SMAD1,5,8 in the developing limb autopod, including the digit domains (Fig. $2 \mathrm{C}$, compare to Fig. 2B). These strong correlations suggest that Id2 expression is associated with BMP signaling. In support of this interpretation, BMP signaling regulates the expression of Id proteins in different cell types (Lopez-Rovira et al., 2002, Nakashima et al., 2001).

To further investigate the control of $/ d 2$ expression in digit morphogenesis, we have performed gain and loss of function experiments for BMP signaling. As mentioned BMPs are major modulators of digit chondrogenesis and its expression in the interdigital tissue is promoting interdigital apoptosis. Ectopic application of BMP proteins in the tip of the digit potentiates chondrogenesis inducing a dramatically enlarged phalanx (Macias et al., 1997, Zuzarte-Luis et al., 2004). We have found that this phenotype is preceded by upregulation of $/ d 2$ in a fashion that prefigures the ectopic outgrowth of such cartilage (Fig. 2D). By contrary, identical treatments with Noggin, a BMP 
antagonist, causes digit growth truncation (Merino et al., 1998). Accordingly, Noggin beads applied at the distal tip of the digit completely abolish the expression of $/ d 2$ (Fig. $2 \mathrm{E}$ ).

\section{TGF $\beta$ s upregulate Id2 in the initial digit aggregates}

A significant feature of this study is the precocious expression of $/ d 2$ in the autopod showing this factor as one of the earliest marker of the digital territory. However, ectopic overexpression of BMPs can only promote the growth of preexisting cartilage in the developing autopod but not the formation of an ectopic one (Macias et al., 1997). In this regard interdigital application of TGF $\beta$ s/Activins, induces the formation of an ectopic digit (Chimal-Monroy et al., 2003, Ganan et al., 1996). Thus, to evaluate the possible implication of Id2 in digit formation, we have explored its regulation when a bead bearing TGF $\beta 1$ was implanted in the interdigital mesenchyme. We have detected a transient induction of $/ d 2$ expression 3 hours after the interdigital implantation of a TGF $\beta$-bead (Fig. 2F) (identical results were found after application of an Activin soaked bead; not shown). This ectopic expression is transient and after 12 hours is substituted by the characteristic domains present at the tip of developing digits. These finding suggest a role for Id2 under the control of TGF $\beta$ s/activins in the initial steps of digit formation.

\section{Chondrocyte proliferation in the digit primordia and expres- sion of Id2}

An interesting aspect of Id2 in limb development is its appearance in chondrocytes of the developing cartilage rudiments. To check whether the digital /d2 expression may reflect zones of proliferation within the developing cartilages we compared the pattern of BdrU incorporation into the digit blastemas (Fig. 3A-C) with the digit domains of Id2(Fig. D-F). As shown in Fig. 3A BrdU digit labeling is uniform at stages 26-27. In subsequent stages labeling of BdrU incorporation becomes progressively divided into domains located in the central core of the phalanxes with higher proliferation in the prospective diaphysis and lower epiphyseal labeling around the zones of joint differentiation (Fig. 3B-C). In sum this pattern resembles the expression of $/ d 2$ indicating a possible role for this factor in cartilage proliferation. In concordance with this finding incorporation of BrdU in the developing tendons was also correlated with the late expression of this gene in the maturing tendons (Fig. 3G).

\section{Expression of Id2 during in vitro chondrogenesis}

To further evaluate the involvement of Id2 in chondrogenesis and its regulation by BMPs, we have studied its expression in the in vitro model system of micromass cultures. As shown in figure 4 (A) transcripts of $/ d 2$ were abundant in the incipient chondrogenic nodes at day 2 of culture. By day 4 of culture expression was maintained in the mature cartilage nodes (Fig. 4B). Furthermore, in consistency with our in vivoobservations, expression of /d2was upregulated, thought at moderate levels, when BMP7 was added to the culture medium (Fig. 4C).

\section{Discussion}

Here we report the pattern of expression and regulation of the inhibitor of DNA binding/differentiation 2(Id2), an helix-loop-helix factor that sequesters $\mathrm{bHLH}$ transcription factors by forming heterodimers that lack the ability to bind DNA. We show that expression of $/ d 2$ in the developing limb corresponds closely with the zones of active BMP signaling. In the early limb bud, Id2 exhibits anterior and posterior mesodermal domains corresponding quite closely with the domains of expression of BMP4, BMP7 and BMP2 (Montero et al., 2001). In addition /d2 is also expressed at low levels in the AER. This structure is a key-signaling center of the limb bud regulated by a complex signaling network, which includes BMPs (Pizette et al., 2001). The expression of /d2 in the $\mathrm{AER}$ and the anterior and posterior mesoderm might be related with the demonstrated function of this transcription factor in maintaining cells in an undifferentiated state. Although we cannot provide a reasonable explanation for the transitory expression of Id2 in the AER, since BMPs are active in this structure until the final stages of limb morphogenesis. Expression of $/ d 2$ in the undifferentiated subectodermal mesoderm at advanced stages of development is also consistent with the function of Id2 in maintaining cells undifferentiated. /d2has been also found in this study in the areas of interdigital cell death outlining the prospective apoptotic territories both in chick and in duck embryos. It is well known that the interdigital tissue requires to be maintained in an undifferentiated state in order to be sensible to cell death-triggering signals. This aspect is manifested by the expression in this tissue of markers of undifferentiation including Msx2 or Snail genes (Ganan et al., 1998, Montero et al., 2001). Taking into account that Id2 appears to be a regulator of undifferentiation (Lyden etal., 1999, Shimizu-Nishikawa et al., 1999) we hypothesized that /d2 expression in the prospective apoptotic tissue might favor the maintenance of the undifferentiated state of the interdigital mesenchyme. However Id2 has been described as an proapototic factor in neurons (Gleichmann et al., 2002). In addition Zhao et al. (2007) have provided some evidences for a possible positive implication of Id2 in apoptotic interdigital cell death in the quail embryo.

A remarkable finding of this study is that $/ d 2$ exhibits characteristic expression domains in differentiating chondrocytes during the formation of the limb skeleton. The chondrogenic aggregates in early limb buds and chondrogenic nodules in micromass cultures are positive for this gene. /d2 is also a precocious marker
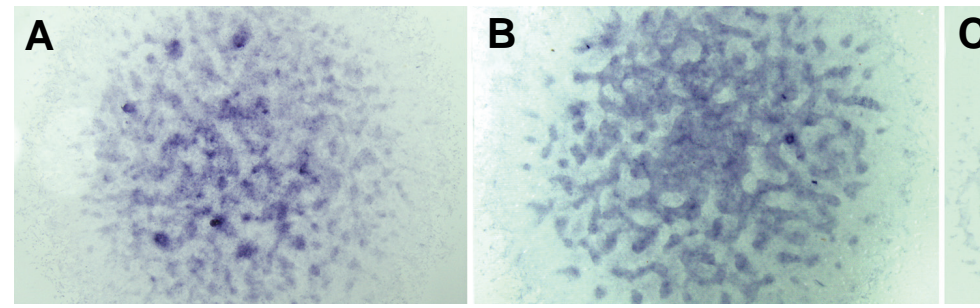

C lage differentiates (B). (C) Id2 expression is moderately upregulated respect to B upon 2 days of treatment with $50 \mathrm{ng} / \mathrm{ml}$ BMP7 protein.

Fig. 4. Id2 expression in chondrogenic micromass cultures. (A-B) Id2 in situ hybridization in micromass cultures after 2 (A) and 4 (B) days of incubation. Note initial labeling in a spotted pattern (A), which is expanded as carti- 
of the digit forming territory and is highly expressed in the tip of the growing digits. In addition, as morphogenesis progresses, /d2 displays well-defined domains in the chondrocytes of the developing phalanxes. Together these findings are consistent with a function of Id2 in chondrogenesis. However, no chondrogenic phenotype was reported in mice deficient for /d2 (Lasorella et al., 2000, Yokota et al., 1999). Taking into account that Id1 and ID3 are expressed in similar patterns in the developing limb (Jen etal., 1996) it is likely that lack of skeletal phenotypes in the single mutants for these genes are due to functional redundancy between members of this family. In this regard it has been shown in vitrothat BMP induces several Id genes when promoting chondroblast differentiation (Liu et al., 2007).

The dynamic domains of /d2 expression, accompanying digit formation might bear different functional significance. The pattern of expression of $/ d 2$ in the diaphysis and epiphysis of the developing phalanxes is rather coincident with zones of higher BrdU incorporation in the digit blastemas prior to hypertrophic differentiation. This pattern of expression is consistent with the role of Id proteins promoting cell proliferation in other systems (Barone et al., 1994, Hara et al., 1994, Lyden et al., 1999, Mori et al., 2000, Rothschild et al., 2006), but not with the inhibition of cell differentiation proposed for this transcription factor. It must be taken into account that, at the stages covered by this study, proliferating chondrocytes of the diaphysis are in course of transformation into prehypertrophic chondrocytes. These findings indicate that the role of Id2 in the developing cartilages is associated with growth rather than maintaining cells undifferentiated. In this regard, it is also significant that /d2transcripts are absent from the developing joints in spite of being formed by a local dedifferentiation of the digit cartilage (Craig et al., 1987).

The early expression of /d2in the prospective digit territories as well as the maintained expression in the mesenchyme of the tip of the growing digits may reflect a specific function in cartilage/ tendon differentiation. As the incipient digit mesenchyme of the early bud, the tip of growing digits is a complex region undergoing cell aggregation (Montero et al., 2007). However upon cell aggregation, the distal mesoderm of the autopod is also able to develop into the precursors of the digit tendons that are formed in close relation with cartilaginous aggregates (Hurle et al., 1990, Schweitzer et al., 2001). At molecular level TGF $\beta$ s/Activins and BMP signaling are confluent at these places. Tgf $\beta$ s are highly expressed in the tendinous condensation, however interdigital application of TGF $\beta$ s induces a cartilaginous aggregate, which is preceded by a transient domain of /d2 expression. In turn, local application of BMPs or Noggin stimulates or inhibits respectively both chondrogenesis and the digit domain of $/ d 2$. It is then likely that the regulation of $/ d 2$ by these signals is related with the specification of the chondrogenic versus the tendinous fates of the undiferentiated cells. Indeed, $/ d 2$ has been involved in the control of cell fate decision between two different cell types in other model systems as the terminal differentiation of different lineages of haematopoietic cells from a common progenitor (Ikawa et al., 2001). Tendons develop in close association with cartilages, and scleraxis, an helix-loop-helix transcription factor promotes the specification of mesenchyme towards the tendon lineage (Asou et al., 2002, Brent et al., 2003). At least in the axial skeleton tendon and cartilaginous fates are alternative and cartilage differentiation is required to actively repress tendon develop- ment (Brent et al., 2005). Therefore it is conceivable that stimulation of $/ d 2$ at the tip of the digits promotes chondrogenesis and avoids tendon differentiation by inhibiton of the basic helix-loophelix transcription factor scleraxis. In this regard, the transient induction of $/ d 2$ following interdigital application of TGF $\beta$ s may repress the effect of TGF $\beta$ s in the promotion of tendinous fate (Liu et al., 1996, Salingcarnboriboon et al., 2003). Furthermore, in consistency with their dramatic effects on the expression of $/ d 2$, BMP signaling inhibits scleraxis while noggin expands its expression (Schweitzer et al., 2001).

The expression of Id2, in the maturing tendons is not contradictory with our interpretation. Maturing tendons express both /d2 and BMPssuggesting that at these stages Id 2 might be promoting the growth of the already differentiated tendon blastemas in a similar fashion to the findings observed here for the developing phalanxes. Maturing tendons express both $/ d 2$ and BMPs and expression of $/ d 2$ correlates with the pattern of BrdU incorporation in the differentiating tendon blastemas in a similar fashion to the findings observed here for the developing phalanxes.

\section{Materials and Methods}

\section{Animal models}

In this work we have employed Rhode Island chick embryos ranging from stages $\mathrm{HH} 20$ to HH32 (Hamburger and Hamilton, 1951) and Royal Pekin duck embryos at days 8 and 9 of incubation.

\section{Processing of the limbs}

The fixation of the limbs was performed by overnight immersion in $4 \%$ paraformaldehyde solution, in $0.12 \mathrm{M}$ phosphate buffer, $\mathrm{pH} 7.4$, at $4^{\circ} \mathrm{C}$. Fixed limbs and were rinsed twice in phosphate-buffered saline/Tween $0.1 \%$. At this point, $100 \mu \mathrm{m}$ thick sections were obtained in a vibrotome. Alternatively tissue was cryoprotected in $10 \%$ sucrose solution (in phosphate buffer), embedded in $7.5 \%$ gelatine (Sigma type A) $10 \%$ sucrose solution and sectioned at $12 \mu \mathrm{m}$ in a cryostat.

\section{Probes and in situ hybridization}

The chicken coding cDNA fragment of the /d2sequence was obtained by RT-PCR from RNA extracts of $\mathrm{HH} 25$ autopods. The following primers were designed:

5' primer, 5' - CCTGCTGTACAACATGAACG-3'

3' primer, 5' - CACTCGCCATTAGTTCTGAGG-3'.

PCR product was cloned into PGEM-T (Promega) and the authenticity of the fragment was confirmed by dideoxy sequencing. The PCR conditions were $94^{\circ} \mathrm{C}, 4$ min and then 35 cycles of $94^{\circ} \mathrm{C}, 20 \mathrm{~s} ; 60^{\circ} \mathrm{C}, 30 \mathrm{~s} ; 72^{\circ} \mathrm{C}$, $60 \mathrm{~s}$; and final extension at $72^{\circ} \mathrm{C}, 10 \mathrm{~min}$. PCR products were subcloned into pGEM T-easy (Promega). Id2 digoxygenin-labeled sense and antisense RNA probes were generated for in situ hybridization analysis. For whole mount or $100 \mu \mathrm{m}$ vibratome sections in situ hybridization, samples were treated with $10 \mathrm{mg} / \mathrm{ml}$ of proteinase $\mathrm{K}$ for 20-30 minutes at $20^{\circ} \mathrm{C}$. Hybridization with digoxigenin-labeled antisense RNA probes was performed at $68^{\circ} \mathrm{C}$. Reactions were developed with BCIP/NBT substrate or with purple AP substrate (Roche). For double labeling, fluorescein- and digoxigenin-labeled probes were hybridised together and detected one after another. Alkaline phosphatase reaction from the first antibody was avoided after labeling by heating at $65^{\circ} \mathrm{C}$ and treatment with $0.1 \mathrm{M}$ glycine$\mathrm{HCl}$ ph2,2 treatments. The fluorescein probe was revealed first using an alkaline phosphatase conjugated anti-fluorescein antiserum (Roche) diluted 1:2000, and Fast Red as the chromogene.

\section{Experimental manipulation of the limb}

The regulation of the /d2 gene by BMPs and TGF $\beta$ was studied by analyzing the effects of local administration of recombinant proteins 
including $0.5 \mu \mathrm{g} / \mu \mathrm{l}$ BMP7 (a gift of Creative Biomolecules, Hopkinton, MA), $0.5 \mu \mathrm{g} / \mu \mathrm{l}$ Noggin (generously donated by Regeneron Pharmaceuticals Inc., Tarrytown) or $10 \mu \mathrm{g} / \mathrm{ml}$ TGF $\beta 1$ (R\&D) into the limb mesoderm, using heparin acrylic beads as carriers (Sigma). After the period of incubation, samples were processed for in situ hybridization. In all the experiments, PBS soaked beads were also implanted as a control.

\section{Immunostaining and confocal microscopy}

For pSMAD1,5,8 (Cell Signaling) immunostaining limbs were dissected and fixed in $4 \%$ PFA and frontal $100 \mu \mathrm{m}$ vibratome sections were taken and bleached in Den't bleach $\left(50 \%\right.$ Methanol, $25 \% \mathrm{H}_{2} 0,15 \% \mathrm{H}_{2} \mathrm{O}_{2}$, $10 \% \mathrm{DMSO}$ ) before incubation $\mathrm{O} / \mathrm{N}$ in primary antibody (dilution $1: 100$ ) at $4^{\circ} \mathrm{C}$, washed in TBS and incubated $\mathrm{O} / \mathrm{N}$ in secondary antibody. Samples were examined with a laser confocal microscope (LEICA LSM 510) by using a Plan-Neofluar 10X, 20X or Plan-Apochromat 63X objectives, and argon ion laser (488 $\mathrm{nm}$ ) to excite FITC fluorescence and an HeNe laser $(543 \mathrm{~nm})$ to excite Texas Red.

\section{Cell proliferation}

Cell proliferation was analyzed by anti-bromodeoxyuridine immunolabeling. For this purpose $100 \mathrm{ml}$ of bromodeoxyuridine (BrdU) solution $(100 \mathrm{mg} / \mathrm{ml})$ was injected on the amniotic sac. After 30 minutes of further incubation, the embryos were fixed in $4 \%$ paraformaldehyde. The autopod was then dissected free and sectioned in the vibrotome. Immunostaining to detect BrdU incorporation was carried out in tissue sections according to the instructions of the manufacturer (Becton Dickinson) using anti-BrdU and FITC-conjugated secondary antibody.

\section{Micromass cultures}

Micromass cultures, BMP7 treatments and in situ hybridization were performed as previously described (Chimal-Monroy et al., 2002).

\section{Akcnowledgements}

We thank Montse Fernandez Calderon and Sonia Perez Mantecon for excellent technical assistance. This work was supported by grants from the Spanish Education and Sciences Ministry to JMH (BFU2005-04210) and to JAM (BFU2005-04393/BMC). JAM is supported by the Ramony Cajal program from the Spanish Education and Sciences Ministry. CILD is a recipient of a predoctoral fellowship from the Spanish Education and Sciences Ministry

\section{References}

ASOU, Y., NIFUJI, A., TSUJI, K., SHINOMIYA, K., OLSON, E.N., KOOPMAN, P. and NODA, M. (2002). Coordinated expression of scleraxis and Sox9 genes during embryonic development of tendons and cartilage. J.Orthop. Res. 20:827833.

BARONE, M.V., PEPPERKOK, R., PEVERALI, F.A. and PHILIPSON, L. (1994). Id proteins control growth induction in mammalian cells. Proc.Nat..Acad.Sci.USA 91:4985-4988.

BENEZRA, R., DAVIS, R.L., LOCKSHON, D., TURNER, D.L. and WEINTRAUB, H. (1990). The protein Id: a negative regulator of helix-loop-helix DNA binding proteins. Cel/61:49-59.

BRENT, A.E., BRAUN, T. and TABIN, C.J. (2005). Genetic analysis of interactions between the somitic muscle, cartilage and tendon cell lineages during mouse development. Development 132:515-528.

BRENT, A.E., SCHWEITZER, R. and TABIN, C.J. (2003). A somitic compartment of tendon progenitors. Cel/113:235-248.

CHIMAL-MONROY, J., RODRIGUEZ-LEON, J., MONTERO, J.A., GANAN, Y., MACIAS, D., MERINO, R. and HURLE, J.M. (2003). Analysis of the molecular cascade responsible for mesodermal limb chondrogenesis: Sox genes and BMP signaling. Dev.Biol. 257:292-301.

CHIMAL-MONROY, J., MONTERO, J.A., GANAN, Y., MACIAS, D., GARCIAPORRERO, J.A. and HURLE, J.M. (2002). Comparative analysis of the expression and regulation of Wnt5a, Fz4, and Frzb1 during digit formation and in micromass cultures. Dev.Dyn. 224:314-320

CRAIG, F.M., BENTLEY, G. and ARCHER, C.W. (1987). The spatial and temporal pattern of collagens I and II and keratan sulphate in the developing chick metatarsophalangeal joint. Development 99:383-391.

FERNANDEZ, P.C., FRANK, S.R., WANG, L., SCHROEDER, M., LIU, S., GREENE, J., COCITO, A. AND AMATI, B. (2003). Genomic targets of the human c-Myc protein. Genes Dev. 17:1115-1129.

GANAN, Y., MACIAS, D., BASCO, R.D., MERINO, R. and HURLE, J.M. (1998). Morphological diversity of the avian foot is related with the pattern of $\mathrm{msx}$ gene expression in the developing autopod. Dev.Biol. 196:33-41.

GANAN, Y., MACIAS, D., DUTERQUE-COQUILLAUD, M., ROS, M.A. and HURLE, J.M. (1996). Role of TGF beta s and BMPs as signals controlling the position of the digits and the areas of interdigital cell death in the developing chick limb autopod. Development 122:2349-2357.

GLEICHMANN, M., BUCHHEIM, G., EL-BIZRI, H., YOKOTA, Y., KLOCKGETHER, T., KUGLER, S., BAHR, M., WELLER, M. and SCHULZ, J.B. (2002). Identification of inhibitor-of-differentiation 2 (Id2) as a modulator of neuronal apoptosis. J.Neurochem. 80:755-762.

GROTEWOLD, L., PLUM, M., DILDROP, R., PETERS, T. and RUTHER, U. (2001). Bambi is coexpressed with Bmp-4 during mouse embryogenesis. Mech.Dev. 100:327-330.

HAMBURGER, V. AND HAMILTON, H. L. (1951). A series of normal stages in the development of the chick embryo. J. Morphol. 88:49-92.

HACKER, C., KIRSCH, RD., JU, X.S., HIERONYMUS, T., GUST, T.C., KUHL, C., JORGAS, T., KURZ, S.M., ROSE-JOHN. S., YOKOTA, Y. AND ZENKE, M. (2003). Transcriptional profiling identifies Id2 function in dendritic cell development. Nat Immunol. 4:380-386.

HARA, E., YAMAGUCHI, T., NOJIMA, H., IDE, T., CAMPISI, J., OKAYAMA, H. and ODA, K. (1994). Id-related genes encoding helix-loop-helix proteins are required for G1 progression and are repressed in senescent human fibroblasts. J.Biol.Chem. 269:2139-2145.

HOLLNAGEL, A., OEHLMANN, V., HEYMER, J., RUTHER, U. and NORDHEIM, A. (1999). Id genes are direct targets of bone morphogenetic protein induction in embryonic stem cells. J.Biol.Chem. 274:19838-19845.

HURLE, J.M., ROS, M.A., GANAN, Y., MACIAS, D., CRITCHLOW, M. and HINCHLIFFE, J.R. (1990). Experimental analysis of the role of ECM in the patterning of the distal tendons of the developing limb bud. Cell Differ.Dev. 30:97-108

IAVARONE, A., LASORELLA, A. (2006). ID proteins as targets in cancer and tools in neurobiology. Trends Mol.Med. 12:588-594.

IKAWA, T., FUJIMOTO, S., KAWAMOTO, H., KATSURA, Y. and YOKOTA, Y. (2001). Commitment to natural killer cells requires the helix-loop-helix inhibito Id2. Proc.Natl.Acad.Sci.USA 98:5164-5169.

JEN, Y., MANOVA, K. AND BENEZRA, AND R. (1996). Expression patterns of Id1, Id2, and Id3 are highly related but distinct from that of Id4 during mouse embryogenesis. Dev Dyn. 207:235-252

KOWANETZ, M., VALCOURT, U., BERGSTROM, R., HELDIN, C.H. and MOUSTAKAS, A. (2004). Id2 and Id3 define the potency of cell proliferation and differentiation responses to transforming growth factor beta and bone morphogenetic protein. Mol. Cell.Biol. 24:4241-4254.

KRISHAN, K., MCKINNELL, I., PATEL, K. and DHOOT, G.K. (2005). Dynamic Id2 expression in the medial and lateral domains of avian dermamyotome. Dev.Dyn. 234:363-370.

LASORELLA, A., NOSEDA, M., BEYNA, M., YOKOTA, Y. and IAVARONE, A. (2000). Id2 is a retinoblastoma protein target and mediates signalling by Myc oncoproteins. Nature 407:592-598.

LASORELLA, A., BOLDRINI, R., DOMINICI, C., DONFRANCESCO, A., YOKOTA Y., INSERRA, A. AND IAVARONE, A. (2002). Id2 is critical for cellular proliferation and is the oncogenic effector of N-myc in human neuroblastoma. Cancer Res. 62:301-306.

LIU, T., GAO, Y., SAKAMOTO, K., MINAMIZATO, T., FURUKAWA, K., TSUKAZAKI, T., SHIBATA, Y., BESSHO, K., KOMORI, T. AND YAMAGUCHI, A. (2007) BMP-2 promotes differentiation of osteoblasts and chondroblasts in Runx2deficient cell lines. J Cell Physiol. 211: 728-35.

LIU, Y., CSERJESI, P., NIFUJI, A., OLSON, E.N. and NODA, M. (1996). Sclerotome-related helix-loop-helix type transcription factor (scleraxis) mRNA is 
expressed in osteoblasts and its level is enhanced by type-beta transforming growth factor. J.Endocrinol. 151:491-499.

LOPEZ-ROVIRA, T., CHALAUX, E., MASSAGUE, J., ROSA, J.L. and VENTURA, F. (2002). Direct binding of Smad1 and Smad4 to two distinct motifs mediates bone morphogenetic protein-specific transcriptional activation of Id1 gene. J.Biol.Chem. 277:3176-3185.

LYDEN, D., YOUNG, A.Z., ZAGZAG, D., et al. (1999). Id1 and Id3 are required for neurogenesis, angiogenesis and vascularization of tumour xenografts. Nature 401:670-677.

MACIAS, D., GANAN, Y., SAMPATH, T.K., PIEDRA, M.E., ROS, M.A. and HURLE, J.M. (1997). Role of BMP-2 and OP-1 (BMP-7) in programmed cell death and skeletogenesis during chick limb development. Development 124:1109-1117.

MASSAGUE, J., SEOANE, J. and WOTTON, D. (2005). Smad transcription factors. Genes Dev. 19:2783-2810.

MARIN-HUSSTEGE, M., HE, Y., LI, J., KONDO, T., SABLITZKY, F. AND CASACCIABONNEFIL, P. (2006). Multiple roles of Id4 in developmental myelination: predicted outcomes and unexpected findings. Glia. 54:285-296.

MERINO, R., MACIAS, D., GANAN, Y., RODRIGUEZ-LEON, J., ECONOMIDES, A.N., RODRIGUEZ-ESTEBAN, C., IZPISUA-BELMONTE, J.C. and HURLE, J.M. (1999a). Control of digit formation by activin signalling. Development 126:2161-2170.

MERINO, R., RODRIGUEZ-LEON, J., MACIAS, D., GANAN, Y., ECONOMIDES, A.N. and HURLE, J.M. (1999b). The BMP antagonist Gremlin regulates outgrowth, chondrogenesis and programmed cell death in the developing limb. Development 126:5515-5522.

MERINO, R., GANAN, Y., MACIAS, D., ECONOMIDES, A.N., SAMPATH, K.T. and HURLE, J.M. (1998). Morphogenesis of digits in the avian limb is controlled by FGFs, TGFbetas, and noggin through BMP signaling. Dev.Biol. 200:35-45.

MONTERO, J.A., HURLE, J.M. (2007). Deconstructing digit chondrogenesis. Bioessays 29:725-737.

MONTERO, J.A., ZUZARTE-LUIS, V., GARCIA-MARTINEZ, V. and HURLE, J.M. (2007). Role of RhoC in digit morphogenesis during limb development. Dev.Biol. 303:325-335

MONTERO, J.A., GANAN, Y., MACIAS, D., RODRIGUEZ-LEON, J., SANZEZQUERRO, J.J., MERINO, R., CHIMAL-MONROY, J., NIETO, M.A. and HURLE, J.M. (2001). Role of FGFs in the control of programmed cell death during limb development. Development 128:2075-2084.

MORI, S., NISHIKAWA, S.I. and YOKOTA, Y. (2000). Lactation defect in mice lacking the helix-loop-helix inhibitor Id2. EMBO J. 19:5772-5781.

NAKASHIMA, K., TAKIZAWA, T., OCHIAI, W., YANAGISAWA, M., HISATSUNE, T., NAKAFUKU, M., MIYAZONO, K., KISHIMOTO, T., KAGEYAMA, R. and TAGA, T. (2001). BMP2-mediated alteration in the developmental pathway of fetal mouse brain cells from neurogenesis to astrocytogenesis. Proc.Natl.Acad.Sci.USA 98:5868-5873.

PIZETTE, S., ABATE-SHEN, C. and NISWANDER, L. (2001). BMP controls proximodistal outgrowth, via induction of the apical ectodermal ridge, and dorsoventral patterning in the vertebrate limb. Development 128:4463-4474.

ROBERTS, E.C., DEED, R.W., INOUE, T., NORTON, J.D. and SHARROCKS, A.D (2001). Id helix-loop-helix proteins antagonize pax transcription factor activity by inhibiting DNA binding. Mol.Cell.Biol. 21:524-533.

ROTHSCHILD, G., ZHAO, X., IAVARONE, A. and LASORELLA, A. (2006). E Proteins and Id2 converge on p57Kip2 to regulate cell cycle in neural cells. Mol. Cell.Biol. 26:4351-4361

RUSSELL RG, LASORELLA A, DETTIN LE, IAVARONE A.(2004). Id2 drives differentiation and suppresses tumor formation in the intestinal epithelium. Cancer Res. 64:7220-7225.

RUZINOVA, M.B., BENEZRA, R. (2003). Id proteins in development, cell cycle and cancer. Trends Cell Biol. 13:410-418.

SABLITZKY, F., MOORE, A., BROMLEY, M., DEED, R.W., NEWTON, J.S. AND NORTON JD. (1998). Stage- and subcellular-specific expression of Id proteins in male germ and Sertoli cells implicates distinctive regulatory roles for Id proteins during meiosis, spermatogenesis, and Sertoli cell function. Cel/ Growth Differ. 12:1015-1024

SALINGCARNBORIBOON, R., YOSHITAKE, H., TSUJI, K., OBINATA, M. AMAGASA, T., NIFUJI, A. and NODA, M. (2003). Establishment of tendonderived cell lines exhibiting pluripotent mesenchymal stem cell-like property. Exp. Cell Res. 287:289-300.

SCHWEITZER, R., CHYUNG, J.H., MURTAUGH, L.C., BRENT, A.E., ROSEN, V., OLSON, E.N., LASSAR, A. and TABIN, C.J. (2001). Analysis of the tendon cell fate using Scleraxis, a specific marker for tendons and ligaments. Development 128:3855-3866

SHIMIZU-NISHIKAWA, K., TAZAWA, I., UCHIYAMA, K. and YOSHIZATO, K. (1999). Expression of helix-loop-helix type negative regulators of differentiation during limb regeneration in urodeles and anurans. Dev. Growth Differ. 41:731 743.

SIKDER, H.A., DEVLIN, M.K., DUNLAP, S., RYU, B. and ALANI, R.M. (2003). Id proteins in cell growth and tumorigenesis. Cancer. Cell. 3:525-530.

YATES, P.R., ATHERTON, G.T., DEED, R.W., NORTON, J.D. and SHARROCKS, A.D. (1999). Id helix-loop-helix proteins inhibit nucleoprotein complex formation by the TCF ETS-domain transcription factors. EMBO J. 18:968-976.

YOKOTA, Y., MANSOURI, A., MORI, S., SUGAWARA, S., ADACHI, S., NISHIKAWA S. and GRUSS, P. (1999). Development of peripheral lymphoid organs and natural killer cells depends on the helix-loop-helix inhibitor Id2. Nature 397:702706.

ZHAO, W., ALLEN, S. AND DHOOT, G.K. (2007). FGF mediated Sulf1 regulation FEBS Lett. 581:4960-4964

ZUZARTE-LUIS, V., MONTERO, J.A., RODRIGUEZ-LEON, J., MERINO, R., RODRIGUEZ-REY, J.C. and HURLE, J.M. (2004). A new role for BMP5 during limb development acting through the synergic activation of Smad and MAPK pathways. Dev.Biol. 272:39-52.

ZUZARTE-LUIS, V., HURLE, J.M. (2002). Programmed cell death in the developing limb. Int.J.Dev.Biol. 46:871-876. 


\section{Further Related Reading, published previously in the Int. J. Dev. Biol.}

See our recent Special Issue Fertilization, in honor of David L. Garbers and edited by Paul M. Wassarman and Victor D. Vacquier at: http://www.ijdb.ehu.es/web/contents.php?vol=52\&issue=5-6

See our recent Special Issue Limb Development edited by Juan Huré and Juan Carlos Izpísua-Belmonte at: http://www.ijdb.ehu.es/web/contents.php?vol=46\&issue=7

Loss of Sox9 function results in defective chondrocyte differentiation of mouse embryonic stem cells in vitro Gunnar Hargus, Ralf Kist, Jan Kramer, Daniela Gerstel, Angela Neitz, Gerd Scherer and Jürgen Rohwedel Int. J. Dev. Biol. (2008) 52: 323-332.

The expression of Fat-1 cadherin during chick limb development Terence G. Smith, Nick Van Hateren, Cheryll Tickle and Stuart A. Wilson Int. J. Dev. Biol. (2007) 51: 173-176

Sclerotome development and morphogenesis: when experimental embryology meets genetics

Anne-Hélène Monsoro-Burq

Int. J. Dev. Biol. (2005) 49: 301-308

Bmp, Fgf and Wnt signalling in programmed cell death and chondrogenesis during vertebrate limb development: the role of Dickkopf-1.

Lars Grotewold and Ulrich Rüther

Int. J. Dev. Biol. (2002) 46: 943-947

Signalling via type IA and type IB bone morphogenetic protein receptors (BMPR) regulates intramembranous bone formation, chondrogenesis and feather formation in the chicken embryo.

Amir M Ashique, Katherine Fu and Joy M Richman

Int. J. Dev. Biol. (2002) 46: 243-253

Programmed cell death in the developing limb.

Vanessa Zuzarte-Luís and Juan M Hurlé

Int. J. Dev. Biol. (2002) 46: 871-876

Developmental expression of chick twist and its regulation during limb patterning.

A T Tavares, J C Izpisúja-Belmonte and J Rodriguez-León

Int. J. Dev. Biol. (2001) 45: 707-713

Developmental control of chondrogenesis and osteogenesis.

R Cancedda, P Castagnola, F D Cancedda, B Dozin and R Quarto

Int. J. Dev. Biol. (2000) 44: 707-714

Interdigital soft tissue separation induced by retinoic acid in mouse limbs cultured in vitro.

M Lussier, C Canoun, C Ma, A Sank and C Shuler

Int. J. Dev. Biol. (1993) 37: 555-564

The role of the polarizing zone in the pattern of experimental chondrogenesis in the chick embryo interdigital space.

D Macías and Y Gañán

Int. J. Dev. Biol. (1991) 35: 63-67

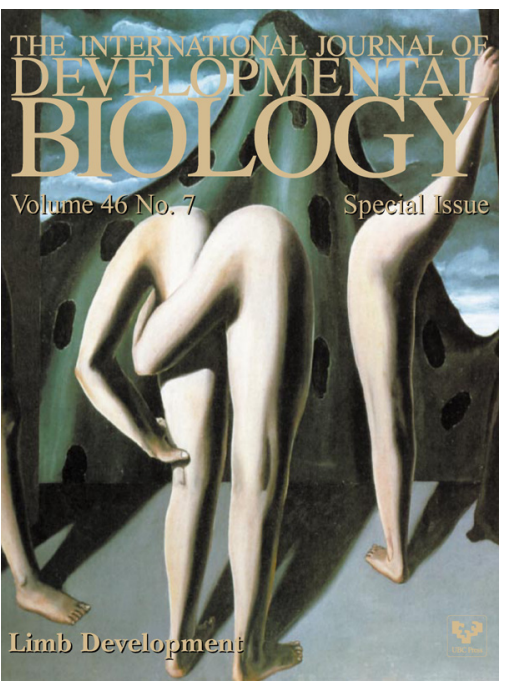

5 yr ISI Impact Factor $(2008)=3.271$

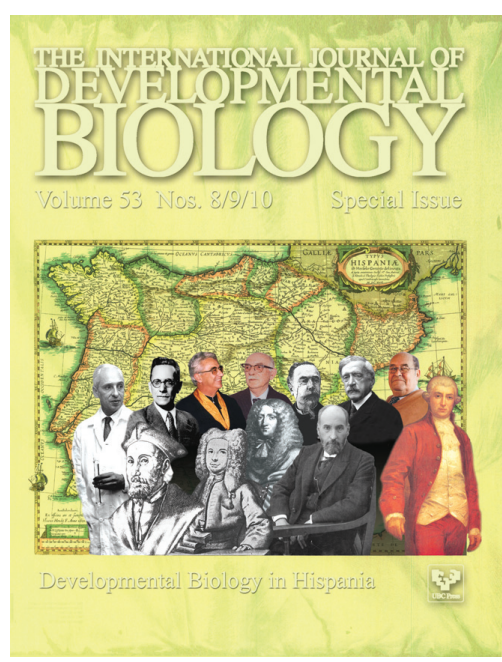

